\title{
Effects of land cover changes and slope gradient on soil quality in the Gumara watershed, Lake Tana basin of North-West Ethiopia
}

\author{
Mesfin Anteneh Wubie ${ }^{1}$ (D) Mohammed Assen ${ }^{2}$
}

Received: 5 January 2019 / Accepted: 7 October 2019 / Published online: 21 October 2019

(c) The Author(s) 2019

\begin{abstract}
This study evaluated land cover change and slope gradient on selected soil quality parameters in the Gumara watershed, northwestern Ethiopia. 36 soil samples were collected from 0- to 20-cm depth under four land cover types across three slope gradients. The collected soil samples were analyzed for selected soil quality parameters. Result indicated that the bulk density of the soil is different $(P<0.001)$ in the watershed because of land cover change and slope gradient. Cultivated land and steeper slopes have the highest bulk density and lowest total porosity. On the other hand, the forestland and gentler slopes have lowest bulk density and high total porosity. Intensive cultivation accompanied by continuous conversion of forestland to cultivated land caused high bulk density and low total porosity. Cation exchange capacity, exchangeable magnesium total nitrogen, available phosphorus and potassium negatively correlated with slope gradient. Conversion of forestland to cultivated land contributed to changes in $\mathrm{pH}(P<0.05)$ exchangeable calcium $(P<0.01)$, potassium $(P<0.001)$, available phosphorus $(P<0.01)$ and nitrogen $(P<0.01)$ content. The soil degradation index results showed that soil organic carbon, nitrogen, available phosphorus and exchangeable potassium contents declined and bulk density increased because of the land cover change. This negative effect on agricultural development and environmental health of the watershed makes an integrated land resource management approach vital for sustaining agricultural productivity and the environment health of the Gumara watershed.
\end{abstract}

Keywords Land use/cover change $\cdot$ Slope gradient $\cdot$ Soil quality $\cdot$ Gumara watershed

\section{Introduction}

Soil as a fundamental natural resource performs key environmental, economic and social functions. These functions of soil vary over space and time governed by a soil quality. The quality of soil is its capacity to function within ecosystem and land use boundaries, to sustain biological productivity, maintain environmental quality and promote plant, animal and human health (Doran et al. 1996). High-quality soil not only produces better food and fiber but also helps to establish natural ecosystems and enhance air and water quality (Griffiths et al. 2010). Capacity of soil in its water absorption

Mesfin Anteneh Wubie mesfin74@yahoo.com

Mohammed Assen

moh_assen@yahoo.com

Bahir Dar University, Bahir Dar, Ethiopia

2 Addis Ababa University, Addis Ababa, Ethiopia and buffering against induced changes, resistance to erosion and damage, supplying of adequate rooting, oxygen and nutrient balances to plants is taken as key indicators of soil quality (Jing et al. 2011). Soil quality changes over time influenced by several factors, such as land-use dynamics (Islam and Weil 2000; Compos et al. 2007) and natural factors like topography (Jing et al. 2011) as well as geomorphic processes, e.g., soil erosion (Buscot 2005).

Over the last decades, some research has been done on land use/cover change and its impact on soil quality dynamics (Lambin et al. 2001). For instance, studies of impacts of land-use change on soil fertility quality in the highlands of Ethiopia (Woldeamlak and Stroosnijder 2003; Mulugeta 2004; Negassa and Heluf 2004) indicate that forest and shrub lands have high fertility quality compared to grass and cultivated areas. Contents of organic matter and total nitrogen $(\mathrm{N})$ of the soil declined due to deforestation and continuous cultivation (Mulugeta 2004). In western Ethiopia, Nega and Heluf (2009) conclude that conversion of natural forest land into grazing land and cultivated lands caused loses of 
cation exchange capacity (CEC) in the magnitude of $38 \%$ and $50 \%$, respectively in the surface $(0-20 \mathrm{~cm})$ soils.

Apart from land-use impacts, local variations in properties of a soil are determined by topographic attributes as it is one of the soil-forming factors (Brubaker et al. 1993; Jing et al. 2011). Topographic factors expressed by elevation, slope gradients and positions play great roles in changing the climatic condition of a given area. These variations in topographic characteristics determine the local spatial variation of soil characteristics. For instance, status of fertility quality shows variation due to variation in topography and slope gradients of the area (Wolde et al. 2007). The upper slope areas had lower nutrient concentrations than lower areas as a result of erosion of top soil and subsequent deposition in the lower slope (Alemayehu 2007). In the same way, Gregorich et al. (1998) observed organic carbon losses in upslope shoulder slope gradient; whereas, gentler slope areas and level depressions undergo organic carbon accumulations. Thus, variation in soil property is caused by a complex of interaction of natural (e.g., slope gradient) and man-made (e.g., land-use dynamics and management) factors. However, the contributions of these factors to the spatial variation of soil quality changes could not be always uniform and cannot be easily predicted. Therefore, the objectives of this study are to assess the impact of land use/cover change and slope gradient variation on the physical and biochemical properties of the soil in the Gumara watershed of the Lake Tana basin, North-West Ethiopia.

\section{Methodology}

\section{Description of the study area}

Gumara watershed is found in northwestern Ethiopia, located between latitudes $11^{\circ} 34^{\prime}-12^{\circ} \mathrm{N}$ and longitudes $37^{\circ} 33^{\prime}-38^{\circ} 11^{\prime} \mathrm{E}$ (Fig. 1). The elevation ranges from $1784 \mathrm{~m}$ to $3408 \mathrm{~m}$ above mean sea level (amsl). It has $1470.20 \mathrm{~km}^{2}$ and forms a part of Lake Tana basin forming the source of Blue Nile, northwestern Ethiopia. A mountainous and hilly dissected terrain with steep slopes characterizes the upper stream whereas an undulating topography and gentle slopes form the downstream parts of the study watershed. The area is drained by numerous smaller streams including Gumara (the largest stream in the watershed) that flows to Lake Tana.

The soils covering much of the watershed can be classified into clay loam, sandy loam and clayey to silt clayey. The clay loam soils are imperfectly to poorly drained soils occupying the Fogera-Dera flood plains adjoining Lake Tana where the Gumara river ends. The well-drained sandy loam soils are very shallow and eroded covering steeper slopes. The clay to silt clay soils occur on nearly level to gently

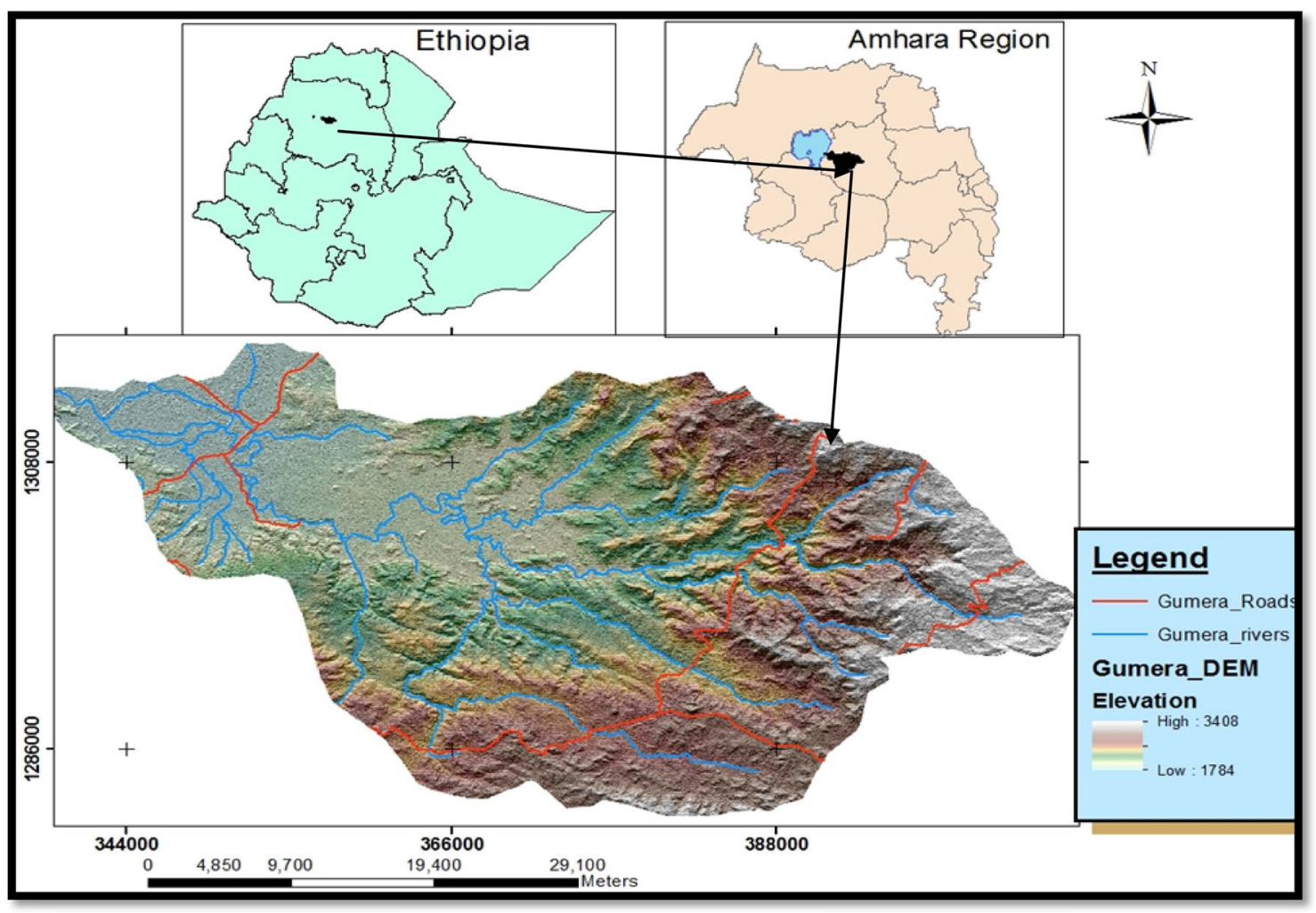

Fig. 1 Location map of the study area 
undulating land occupying the mid-stream and downstream parts of the watershed.

The climatic type is generally humid (EMS 2013). The mean annual temperature is $20.5{ }^{\circ} \mathrm{C}$ and the average total annual rainfall is $1300 \mathrm{~mm}$. More than $75 \%$ of the total rainfall occurs in the months of June to September (kiremt season) (Fig. 2). Corresponding to topographic variation, different natural vegetation types were observed in the area. As a result, Juniperus podocarpus (locally called Zigba) and Juniperus procera (locally referred to as Tid) were found at elevation of 3000 masl. Whereas Dodonaea anguistifola (locally known as Kitkita) and Euclea schimpera (known locally as Dedeho) were found between 1900 and 2200 masl. Syzygium guineense (locally known as Doqima) and Ficus sp. (locally named as warka) were found in gentler slopes and along stream banks.

The total population of the watershed was 198,879 (1984) and 485,816 (2007) and 487,576 (2013) (CSA 2007; South Gondar Zone Office of Agriculture 2013). This gave a corresponding population density of $135.2 \mathrm{p} / \mathrm{km}^{2}, 330.4 \mathrm{p} /$ $\mathrm{km}^{2}$ and $331.7 \mathrm{p} / \mathrm{km}^{2}$. Subsistence mixed (crop and animal) agriculture is the major means of livelihood in the area with an average farm size of about one hectare (ha). The common growing crops are maize (Zea mays L.), teff (Eragrostis teff Zucc), rice (Oryza galberrima) and beans (Phaseolus vulgaris L.). Other less important crops include chickpea (Cicer arietinum), potato (Solanum tuberosum), onion (Allium cepa), cabbage (Brassia aleracea) and Chili pepper (Capsicum spp.). Various types of crops such as garlic (Allium sativum), Ethiopian mustard (Brassica carinata), oats (Avena sativa) and carrot (Daucus carota sativus) are also cultivated as cash crops. Domestic animals such as cattle, goat, sheep, donkey, chicken and bees are kept on traditional basis.

\section{Soil-sampling procedures}

Major land use/cover types were identified according to biophysical factors and dominant human activities (Table 1). For the sake of this study, soil-sampling sites were selected by stratifying the catchment based on the dominant LC types and difference in slope gradient. The whole catchment was classified into three slope gradient categories: gentle (1-14\%), moderate (15-29\%) and steeper slope (30-45\%). Soil samples were taken from the four land cover types of each slope gradient category from November to December, 2015. All sampling points were georeferred with Global Positioning System (GPS). Clinometers were used to measure slope gradients of soil-sampling sites. From topsoil $(0-20 \mathrm{~cm})$, three replicated disturbed samples were collected from five end points of $\times$ mark of each representative land use/cover classes from each slope gradient category (gentle $9 \%$; moderate $22 \%$; and Steeper 36\%). Then 36 disturbed soil samples (4 land-use cover categories, $3 \times$ replicate samples, and $3 \times$ slope gradient categories) were collected. In the same way, undisturbed soil samples for some selected
Fig. 2 Mean annual rainfall and temperature characteristics of the Gumara catchment (Ethiopian Meteorological Service (EMS) 2014)

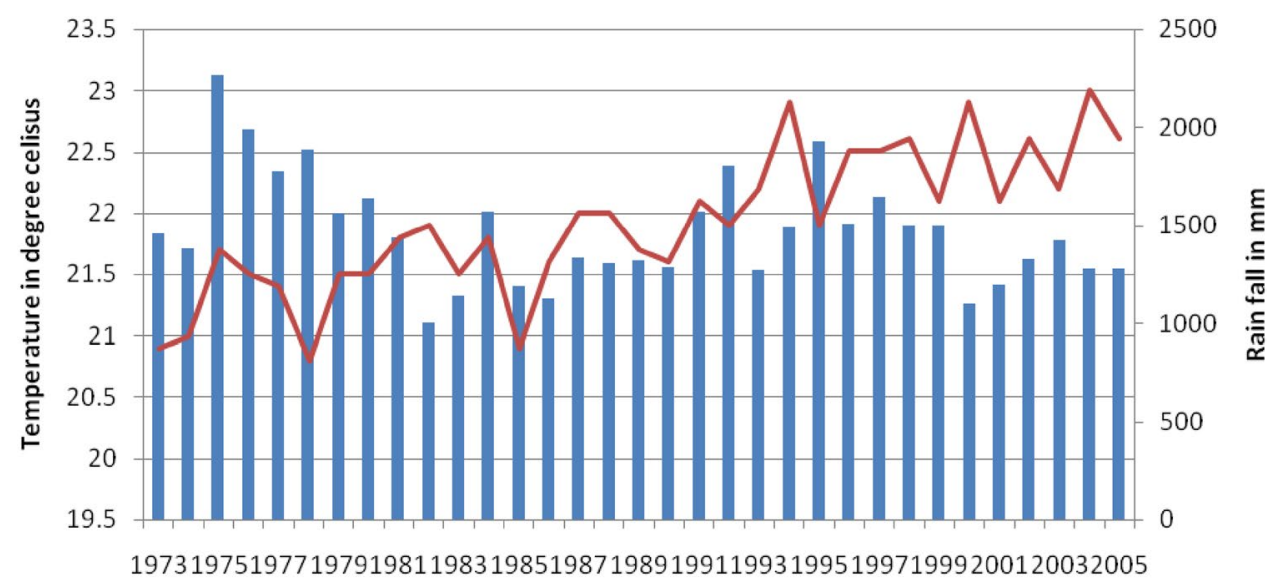

Rain fall in $\mathrm{mm} \longrightarrow$ Temperature in oc
Table 1 Major land use/cover classes

\begin{tabular}{ll}
\hline Land use/cover category & Land cover description \\
\hline Cultivated land (CL) & Areas used for annual crop cultivation \\
Forest land (FL) & Areas covered by trees both natural and planted \\
Shrub land (SL) & Areas covered with shrubs, bushes and small trees \\
Grazing land (GL) & Grasslands used for communal grazing \\
\hline
\end{tabular}


soil physical analysis from the surface (0-20-cm depth) are extracted with a help of core sampler of known volume. The collected disturbed soil samples were mixed in a tray and homogenized into single composite samples for laboratory analysis. The soil was then air-dried, grounded and passed through a 2-mm sieve for laboratory analysis. Assessment of the soil quality is indirectly done when measuring the dynamic soil properties, which serve as indictors of soil functions. The selection of soil quality indicators varies according to soil functions and the intended management goal. Since the main purpose of assessing soil quality in this study is to evaluate its status for crop production, only the soil parameters that are crucial for plant growth such as SOC, N, P, K and bulk density were considered.

\section{Soil laboratory analysis}

Soil bulk density values were measured in undisturbed soil samples taken with a known volume of core ring samplers after drying the soil samples in an oven at $105^{\circ} \mathrm{C}$ to constant weights. Soil particle size distribution was determined by the Bouyoucos hydrometric method (Bouyoucos 1962). The $\mathrm{pH}$ of the soil was measured in water and potassium chloride suspension in 1:2.5 (soil:liquid ratio) (Van Reeuwijk 1992). The Walkley and Black (1934) wet digestion method was used to estimate the organic carbon and the content of organic matter was obtained by multiplying the content of organic carbon by a factor of 1.724 . Total $\mathrm{N}$ was analyzed using Kjeldahl digestion, distillation and titration method as described by Black et al. (1965). The available phosphorous $(\mathrm{P})$ was analyzed according to the standard procedure of Olsen method (Olsen 1954). Cation exchange capacity (CEC) and exchangeable bases were determined by ammonium acetate $\left(\mathrm{NH}_{4} \mathrm{OAC}\right)$ method at $\mathrm{pH}$ 7.0. Exchangeable $\mathrm{Ca}$ and $\mathrm{Mg}$ in the extracts were analyzed using atomic absorption spectrometer (AAS), while $\mathrm{Na}$ and $\mathrm{K}$ were analyzed by flame photometer (Rowell 1994). The CEC was determined by percolating the $\mathrm{NH}_{4} \mathrm{OAC}$ extract by $10 \% \mathrm{NaCl}$ (Chapman 1995). Percentage base saturation (PBS) was calculated by dividing the sum of exchangeable bases ( $\mathrm{Ca}, \mathrm{Mg}, \mathrm{Na}$ and $\mathrm{K}$ ) by the CEC of the soil and multiplying it by 100 . CEC-clay ratio was determined by dividing CEC values by the total clay content of the soil and multiplying the value by 100 . Total porosity was calculated by dividing the values of the bulk density by an assumed particle density of $2.65 \mathrm{~g} / \mathrm{cm}^{3}$ and multiplying the result by 100 .

\section{Soil degradation index}

Soil degradation index (SDI) was computed on the assumption that the status of soil properties under the cultivated land, grazing land and shrub lands was once similar to less disturbed forestland. Accordingly, the difference between the mean values of soil properties under cultivated land, grazing land and shrub land was compared with mean values of soil properties under forestland and expressed as a percentage of the mean value of individual properties (Lukman 2004). After percentages of the required soil properties were averaged, the soil degradation index was computed by considering the values of important soil parameters such as soil organic carbon, nitrogen, phosphorous, potassium and a bulk density for plant growth.

To get supportive idea about the degradation of soil and the perception of farmers in the cause and consequences of soil fertility decline in the study watershed, 120 households were selected from each slope gradient category through systematic sampling technique. Moreover, focus group discussion (FGD) was made with different groups of societies in the watershed to get qualitative information about the level of understanding of farmers regarding the environmental protection and future sustainable land management options.

\section{Data analysis}

The physical and chemical properties of the soil obtained from the soil analyses were subjected to two-way analysis of variance (ANOVA) to find out the influence of land cover change and slope gradient variation on the selected soil quality parameters and their interaction effects using the general linear model (GLM) procedure using SPSS version 20. The Fisher's least significant difference (LSD) was used to separate significantly differing treatment means after main effects were found significant at $(P \leq 0.05)$. Moreover, the Pearson correlation coefficient analysis was applied to determine the relationship between some soil variables, land cover types, and slope gradient. Multiple comparisons were also computed to check if there are differences within or between groups. Data on the perception of households regarding the cause and consequences of soil degradation were analyzed using statistical frequency distribution analysis method. The data obtained from the focus group participants were analyzed qualitatively and used to substantiate results obtained through questionnaire.

\section{Result and discussion}

\section{Impacts of land cover types and slope gradient on soil physical property}

\section{Soil bulk density}

Soil bulk density was significantly affected by land-use types. In fact, bulk density is significantly varied with landuse types due to difference in land management and land-use 
history (Moges and Holden 2008). The highest mean (1.42 g/ $\mathrm{cm}^{3}$ ) value of bulk density was observed under the grazing land and the lowest mean $\left(1.31 \mathrm{~g} / \mathrm{cm}^{3}\right)$ under the forestland at all the slope gradients. Pondo et al. (2004) also found higher soil bulk density values in grazing lands compared to other land-use types. Compaction resulting from intensively grazing animal might have caused a relatively high bulk density in grazing land than that of cultivated land. In contrast, the research conducted in Ethiopia by Husien et al. (2015) reported higher bulk density values in cultivated land than in woodland and shrubland.

The present result indicated the existence of significant $(P<0.001)$ effect of slope gradient on soil bulk density (Table 2). The mean soil bulk density value in the steep slope was the highest $\left(1.51 \mathrm{~g} / \mathrm{cm}^{3}\right)$ which was 7 and $12 \%$ higher over the moderate $\left(1.34 \mathrm{~g} / \mathrm{cm}^{3}\right)$ and gentler $(1.27 \mathrm{~g} /$ $\mathrm{cm}^{3}$ ) slope gradients, respectively. This indicates that the removal of fine particles from higher slope leaves higher concentration of coarser particles behind that causes higher bulk densities in such sites. For this reason, we found significant and negative relation of bulk density with clay $\left(r=-0.95^{* *}\right)$ fraction and significant and positive relation of bulk density with sand $\left(r=0.81^{* *}\right)$ fraction. Besides, bulk density had significant and negative relation with soil organic carbon (SOC) $\left(r=-0.56^{* *}\right)$. The correlation indicates that the presence of relatively higher clay fraction and SOC lowers soil bulk density. In line with this, Achalu et al. (2012) revealed that organic carbon decreases bulk density through its positive effect on soil aggregation.

\section{Total porosity}

The average values of total porosity of grazing land, cultivated land, shrubland and forestland were 48, 48.51, 49.69 , and $50.87 \%$, respectively. Total porosity of a soil

Table 2 Variation of Total porosity with land use and slope gradient

\begin{tabular}{llll}
\hline Land use & Slope gradient & $\begin{array}{l}\text { Mean bulk } \\
\text { density }\end{array}$ & $\begin{array}{l}\text { Mean total } \\
\text { porosity }\end{array}$ \\
\hline Cultivated land & Steep slope & 1.51 & 44.52 \\
& Moderate slope & 1.32 & 47.19 \\
& Gentle slope & 1.28 & 53.84 \\
Forestland & Steep slope & 1.45 & 45.02 \\
& Moderate slope & 1.26 & 52.64 \\
Grazing land & Gentle slope & 1.23 & 54.96 \\
& Steep slope & 1.58 & 43.39 \\
& Moderate slope & 1.36 & 47.16 \\
Shrubland & Gentle slope & 1.32 & 53.45 \\
& Steep slope & 1.50 & 44.63 \\
& Moderate slope & 1.37 & 50.24 \\
& Gentle slope & 1.26 & 54.22 \\
\hline
\end{tabular}

was influenced by change in slope gradient $(P<0.001)$ and land use $(P<0.05)$ (Table 2$)$. The highest total porosity $(50.87 \%)$ found in the forestland compared to grazing land (48\%) caused a $7 \%$ decline in porosity. This result indicated that the conversion of forestland to cropland accompanied by intensive cultivation without appropriate soil management caused a declining pattern of total porosity of the soil.

The mean total porosity content of the interaction of land-use type by slope gradient was significantly different $(P<0.05)$ from each other (Table 5). Considering the interaction effect of land use by slope gradient, the highest interaction mean value of total porosity $(54.96 \%)$ was obtained in the gentle slope of forestland whereas the lowest value $(42.13 \%)$ was observed in the steep slope of shrubland (Table 2). As a result, the total porosity of the soil in the Gumara watershed increases with the decreasing of slope gradient. This is related to the accumulation of contents of organic matter and clay that maximize the level of the total porosity of soil in the gentler slopes of the watershed. Higher total porosity can make the soil workable and will have favorable plant rooting conditions. The reduction in total porosity may have a negative impact on the infiltration capacity and moisture content of the soil. As a consequence, sandy soils of the steeper slope gradient of the study area will have lower contents of moisture availability for plant growth. Moreover, soils with high total porosity (e.g., clayey soil in the gentler slope areas of the study watershed) possibly results in surface water accumulation which can initiate soil erosion. From these points of view, soil and water management technology selection and implementation should consider the texture of the soil and the slope gradients of the study area.

\section{Soil texture class}

The texture of the soil in the study watershed showed variation in terms of land use and slope gradient. Accordingly, the highest average sand content (35\%) was observed under the cultivated land and the lowest (31\%) was recorded in the forestland. On the other hand, the lowest silt fraction (30\%) was recorded in grazing land while the highest silt content $(35 \%)$ in shrubland where as the highest $(36 \%)$ and lowest (30\%) of clay was found on forestland and cultivated land, respectively (Table 3 ).

The clay content varied from 27 to $40 \%$ in all slope gradients. The clay content increased as one moves from the steeper to gentler slope areas of the watershed. The result could be due to deposition from up land areas, resulting into enrichment of the low-lying area.

The silt content varied from $32.2 \%$ at both steeper and moderate slope gradients to $35 \%$ in the gentle slope gradients. This shows a removal of silt content from the moderate and steeper slopes and its counter deposition in the 
Table 3 Variations of soil particle size classes by land-use type

\begin{tabular}{lllll}
\hline Land use & \multicolumn{4}{l}{ Mean value of soil particle (\%) } \\
\cline { 2 - 5 } & Sand & Silt & Clay & Total \\
\hline Cultivated land & 35 & 34.4 & 30.6 & 100 \\
Forestland & 31.76 & 31.82 & 36.42 & 100 \\
Grazing land & 33.91 & 30.86 & 34.77 & 100 \\
Shrubland & 32 & 35 & 33 & 100 \\
\hline
\end{tabular}

gentler slope gradients. This indicates that the geomorphic process in the study catchment is strong enough to detach and remove both finer and medium-sized particles to lower slope gradients. As a consequence, relatively high concentration of contents of sand (39.5\%) was observed in the steeper slope gradient areas compared to the moderate and gentler slope gradients. This confirms that erosion is a selective process that can remove clay and silt particles and leave the coarse fragments behind. Li and Lindstrom (2001) also observed a linear decrease in clay content and a corresponding increase of sand content in the steeper slope due to the selective removal of fine particles by water.

\section{Impacts of land cover types and slope gradient on the chemical soil quality parameters}

\section{Soil pH}

Table 4 shows that soil $\mathrm{pH}$ values varied from 5.77 to 6.64 . The $\mathrm{pH}$ value observed in the study area is within the ranges of moderately acidic to slightly acidic. Soil $\mathrm{pH}$ was significantly affected by land use $(P<0.001)$ and slope gradient $(P<0.05)$ (Table 5). Transformation of land from forest to cultivated land caused a reduction of soil $\mathrm{pH}$ value in the study watershed. As a result, the highest (6.64) and the lowest (5.77) soil $\mathrm{pH}$ values were recorded under the forest and the cultivated land, respectively. The multiple comparison result also showed that $\mathrm{pH}$ content of the soil differed $(P<0.001)$ between cultivated and forest land as well as between grazing land and forest land $(P<0.01)$ (Table 6). The lowest value of $\mathrm{pH}$ under the cultivated land reflects a presence of intensive cultivation and the removal of the basic cations during crop harvest and consequent drainage to the nearby streams due to runoff caused by accelerated erosion.

Considering the slope gradient, the highest and lowest mean value of $\mathrm{pH}$ (6.44) and (5.77) were observed in the gentler and steeper slope gradients, respectively (Table 4). The multiple comparisons indicated that $\mathrm{pH}$ differed $(P<0.001)$ between gentler and steeper slope gradients (Table 6). The study in Canada by Hendershot et al. (1992) also reported that the concentration of $\mathrm{pH}$ is higher in the gentler slopes compared to the steeper slopes. The higher soil $\mathrm{pH}$ values in the gentler slope gradient could be attributed to the accumulation of bases that were presumed to have been removed from the top to the bottom slope position (Garcia et al. 1990). The lowest value of $\mathrm{pH}$ at the higher slope gradients is due to loss of basic cations through run off which in turn increases the activity of $\mathrm{H}^{+}$ion in the soil solution, reduces the soil $\mathrm{pH}$ and increases soil acidity. The other reason for the reduction of soil $\mathrm{pH}$ in steeper slopes might be related to the difference in the management practices such as crop rotation and fertilization rate.

\section{Soil organic carbon}

Contents of soil organic carbon (SOC) ranged between 1.64 and $3.44 \%$ (Table 4). SOC content of less than $2 \%$ is considered very low (Landon 1994). In this study, soil organic carbon content was significantly $(P<0.01)$ affected by land-use change and slope gradient $(P<0.05)$ (Table 5). This result is similar to Bovine et al. (2000) that indicated SOC shows significant variation in landuse change and slope gradient. Amount of soil organic carbon was relatively high (3.44\%) under forest land and

Table 4 Mean value of soil biochemical properties as influenced by land-use type and slope gradient

\begin{tabular}{|c|c|c|c|c|c|c|c|}
\hline \multirow[t]{2}{*}{ Soil parameters } & \multicolumn{4}{|l|}{ Land cover types } & \multicolumn{3}{|c|}{ Slope gradient } \\
\hline & Cultivated land & Grazing land & Forestland & Shrubland & Gentle & Moderate & Steeper \\
\hline $\mathrm{pH}\left(\mathrm{H}_{2} \mathrm{O}\right)$ & 5.77 & 6.00 & 6.67 & 6.20 & 6.44 & 6.20 & 5.77 \\
\hline $\mathrm{CEC}\left(\mathrm{cmol}_{\mathrm{c}}(+) / \mathrm{kg}\right)$ soil & 19.91 & 25.21 & 32.69 & 30.15 & 29.23 & 27.76 & 24.03 \\
\hline $\mathrm{Ca}\left(\mathrm{cmol}_{\mathrm{c}}(+) / \mathrm{kg}\right)$ soil & 14.33 & 16.32 & 17.33 & 15.66 & 19.25 & 16.75 & 12.75 \\
\hline $\mathrm{Ma}\left(\mathrm{cmol}_{\mathrm{c}}(+) / \mathrm{kg}\right)$ soil & 0.86 & 1.24 & 1.91 & 1.31 & 1.74 & 1.14 & 1.11 \\
\hline $\mathrm{Na}\left(\mathrm{cmol}_{\mathrm{c}}(+) / \mathrm{kg}\right)$ soil & 0.25 & 0.47 & 0.83 & 0.42 & 0.45 & 0.44 & 0.56 \\
\hline $\mathrm{K}\left(\mathrm{cmol}_{\mathrm{c}}(+) / \mathrm{kg}\right)$ soil & 0.42 & 0.81 & 1.31 & 0.88 & 1.03 & 0.80 & 0.70 \\
\hline $\mathrm{P}\left(\mathrm{mg} / \mathrm{kg}^{2}\right)$ & 4.39 & 3.25 & 5.20 & 3.97 & 4.98 & 3.87 & 3.76 \\
\hline $\operatorname{SOC}(\%)$ & 1.64 & 2.49 & 3.44 & 2.88 & 2.94 & 2.64 & 2.16 \\
\hline Total nitrogen $(\%)$ & 0.06 & 0.10 & 0.14 & 0.09 & 0.13 & 0.09 & 0.07 \\
\hline CEC/clay & 89.79 & 104.80 & 113.10 & 102.32 & 97.87 & 107.19 & 103.35 \\
\hline
\end{tabular}


Table 5 Interaction effect of land covers types and slope gradients on soil physical and chemical properties

\begin{tabular}{|c|c|c|c|c|c|c|}
\hline Soil parameter & $\begin{array}{l}\text { Frequency } \\
\text { land-use type }\end{array}$ & $P$ value & $\begin{array}{l}\text { Frequency } \\
\text { slope gradi- } \\
\text { ent }\end{array}$ & $P$ value & $\begin{array}{l}\text { Frequency } \\
\text { land-use* slope } \\
\text { gradient }\end{array}$ & $P$ value \\
\hline Clay (\%) & 0.88 & $0.46 \mathrm{~ns}$ & 136.1 & $0.0 * * *$ & 1.23 & $0.321 \mathrm{~ns}$ \\
\hline Silt (\%) & 0.75 & $0.53 \mathrm{~ns}$ & 3.45 & $0.482 \mathrm{~ns}$ & 1.24 & $0.332 \mathrm{~ns}$ \\
\hline Sand (\%) & 1.59 & $0.21 \mathrm{~ns}$ & 97.08 & $0.001 * *$ & 1.42 & $0.246 \mathrm{~ns}$ \\
\hline $\mathrm{BD}\left(\mathrm{g} / \mathrm{cm}^{3}\right)$ & 6.32 & $0.003 * *$ & 35.25 & $0.0 * * *$ & 0.48 & $0.810 \mathrm{~ns}$ \\
\hline $\mathrm{Tp}(\%)$ & 3.04 & $0.480 \mathrm{~ns}$ & 26.56 & $0.001 * *$ & 0.70 & $0.642 \mathrm{~ns}$ \\
\hline $\mathrm{pH}\left(\mathrm{H}_{2} \mathrm{O}\right)$ & 8.55 & $0.0 * * *$ & 10.59 & $0.012 *$ & 1.35 & $0.273 \mathrm{~ns}$ \\
\hline $\mathrm{CEC}\left(\mathrm{cmol}_{\mathrm{c}}(+) / \mathrm{kg}\right)$ & 36.5 & $0.011 * *$ & 105.4 & $0.001 * *$ & 1.67 & $0.171 \mathrm{~ns}$ \\
\hline $\mathrm{Ca}\left(\mathrm{cmol}_{\mathrm{c}}(+) / \mathrm{kg}\right)$ & 42.6 & $0.001 * *$ & 358.8 & $0.013^{*}$ & 2.4 & $0.058 \mathrm{~ns}$ \\
\hline $\mathrm{Na}\left(\mathrm{cmol}_{\mathrm{c}}(+) / \mathrm{kg}\right)$ soil & 82.16 & $0.0 * * *$ & 7.19 & $0.004 * *$ & 4.2 & $0.004^{*}$ \\
\hline $\mathrm{Mg}\left(\mathrm{cmol}_{\mathrm{c}}(+) / \mathrm{kg}\right)$ soil & 1.82 & $0.160 \mathrm{~ns}$ & 1.36 & $0.816 \mathrm{~ns}$ & 1.44 & $0.238 \mathrm{~ns}$ \\
\hline $\mathrm{K}\left(\mathrm{cmol}_{\mathrm{c}}(+) / \mathrm{kg}\right)$ & 408 & $0.002 * *$ & 144.08 & $0.001 * *$ & 15.98 & $0.001 * *$ \\
\hline $\mathrm{P}\left(\mathrm{mg} / \mathrm{kg}^{2}\right)$ & 5.73 & $0.004 * *$ & 5.28 & $0.012^{*}$ & 1.47 & $0.229 \mathrm{~ns}$ \\
\hline $\mathrm{OC}(\%)$ & 27.81 & $0.001 * *$ & 12 & $0.0 * * *$ & 1.72 & $0.159 \mathrm{~ns}$ \\
\hline $\mathrm{TN}(\%)$ & 30.2 & $0.014 *$ & 36.26 & $0.013^{*}$ & 1.93 & $0.117 \mathrm{~ns}$ \\
\hline $\mathrm{C} / \mathrm{N}$ & 3.04 & $0.031 *$ & 1.04 & $0.024 *$ & 3.74 & $0.541 \mathrm{~ns}$ \\
\hline CEC/clay & 41.14 & $0.013 *$ & 11.18 & $0.021 *$ & 2.08 & $0.921 \mathrm{~ns}$ \\
\hline
\end{tabular}

$* P=0.05, * * P=0.01, * * * P=0.001$ low in cultivated lands (1.64\%) (Table 4). The decline in SOC contents in the cultivated land following deforestation and conversion to cultivated lands might have been aggravated by the insufficient application of organic carbon from the farming system due to residue removal and absence of crop rotation. This idea was substantiated by different scholars (Duff and Rasmusen-Smiley 1995; Grace et al. 1995). In addition, leaching problem that can be attributed to the relatively high sand content in the steeper slope and the resultant light texture of soil in the gentler slope areas might have contributed to the reduction of SOC in the steeper slope compared to the gentler slope of the watershed. The multiple comparison result showed that the SOC content of soil differed $(P<0.001)$ between all land-use types (Table 6).

With regard to the interaction between SOC and slope gradient, the highest $(3.03 \%)$ and the lowest $(2.16 \%)$ values of SOC contents were recorded on the gentler and steeper slope gradients, respectively (Table 4). The highest concentration of the SOC in the gentler slope gradients is caused by differences in geomorphic processes of erosion in steeper slopes and deposition in gentler slope gradients in such sites. The multiple comparisons also indicated that there is significant difference of soil organic carbon content between steeper and moderate slope gradient $(P<0.01)$ (Table 6$)$. Thus, the geomorphic processes conditioned by slope gradient factors must be considered in the practices of land management strategies.

\section{Total nitrogen}

Total nitrogen content of the soil was $(P<0.01)$ influenced by the land-use types and slope gradient (Table 5). It accounted a maximum of $0.19 \%$ in the forestland and a minimum of $0.08 \%$ in the cultivated land (Table 4). Thus, this showed $30 \%$ depletion of total nitrogen due to the conversion of virgin land to cultivated land. A similar conclusion was made for the soils of Bako area of central Ethiopia (Wakene 2001). The considerable reduction of total nitrogen in cultivated land could be related to the rapid mineralization of the organic substrates derived from root biomass following intensive cultivation (McDonagh et al. 2001). The highest nitrogen content under forestland resulted from nutrient recycling as the amount extracted returned to the soil as leaf litter. The average nitrogen content decreased considerably from $0.19 \%$ in the gentle slope to $0.10 \%$ in the steep slope gradients which shows a reduction of total nitrogen by about $69 \%$ in the steep slope areas of the watershed compared to gentler slope gradients. The multiple comparison result clearly indicated that $(P<0.001)$ there is a significant variation in the soil content of total nitrogen between all land-use types in all slope gradients of the study watershed (Table 6). The gentler lands of the study watershed are not susceptible to soil erosion thereby leading accumulation of nitrogen and other soluble elements as discussed earlier. On the other hand, the steeper slope lands are highly susceptible to runoff and erosion that caused removal of nitrogen from 
Table 6 LSD post hoc multiple comparison of soil property for slope gradient and land cover types of the Gumara watershed

\begin{tabular}{|c|c|c|c|c|}
\hline \multirow[t]{2}{*}{ Soil parameter } & \multicolumn{2}{|l|}{ Land use } & \multicolumn{2}{|l|}{ Slope gradient } \\
\hline & $\begin{array}{l}\text { Significant contrast value of } \\
\text { soil property }\end{array}$ & $P$ value & $\begin{array}{l}\text { Significant contrast } \\
\text { value of soil property }\end{array}$ & $P$ value \\
\hline \multirow[t]{2}{*}{ Clay (\%) } & & & Steep/moderate & $0.0 * * *$ \\
\hline & & & Moderate/gentle & $0.001 * * *$ \\
\hline Silt (\%) & & & Steep/moderate & $0.015 * *$ \\
\hline \multirow[t]{2}{*}{ Sand $(\%)$} & & & Steep/moderate & $0.0 * * *$ \\
\hline & & & Gentle/steep & $0.001 * * *$ \\
\hline \multirow[t]{2}{*}{$\mathrm{BD}\left(\mathrm{g} / \mathrm{cm}^{3}\right)$} & Shrubland/forestland & $0.003 * * *$ & Moderate/steep & $0.0 * * *$ \\
\hline & Forestland/grazing land & $0.0 * * *$ & Steep/moderate & $0.002 * * *$ \\
\hline \multirow[t]{2}{*}{$\operatorname{Tp}(\%)$} & Grazing land/shrubland & $0.006^{* *}$ & Steep/moderate & $0.001 * * *$ \\
\hline & & & Gentle/steep & $0.0 * * *$ \\
\hline \multirow[t]{2}{*}{$\mathrm{pH}\left(\mathrm{H}_{2} \mathrm{O}\right)$} & Cultivated land/forestland & $0.0 * * *$ & Gentle/steep & $0.0^{* * *}$ \\
\hline & Grazing land/forestland & $0.003 * * *$ & Steep/moderate & $0.004 * * *$ \\
\hline \multirow[t]{2}{*}{$\mathrm{CEC}\left(\mathrm{cmol}_{\mathrm{c}}(+) / \mathrm{kg}\right)$ soil } & Cultivated land/grazing land & $0.0 * * *$ & Steep/moderate & $0.0 * * *$ \\
\hline & Shrubland/forestland & $0.0 * * *$ & Moderate/gentle & $0.001 * * *$ \\
\hline \multirow[t]{2}{*}{$\mathrm{Ca}\left(\mathrm{cmol}_{\mathrm{c}}(+) / \mathrm{kg}\right)$ soil } & Grazing land/cultivated land & $0.001 * * *$ & Moderate/steep & $0.0 * * *$ \\
\hline & Cultivated land/shrubland & $0.0 * * *$ & Gentle/moderate & $0.0^{* * *}$ \\
\hline \multirow[t]{2}{*}{$\mathrm{Na}\left(\mathrm{cmol}_{\mathrm{c}}(+) / \mathrm{kg}\right)$ soil } & Cultivated land/shrubland & $0,0^{* * *}$ & Steep/gentle & $0.015 * *$ \\
\hline & Grazing land/forestland & $0.001 * * *$ & Moderate/steep & $0.001 * * *$ \\
\hline $\mathrm{Mg}\left(\mathrm{cmol}_{\mathrm{c}}(+) / \mathrm{kg}\right)$ soil & & & Gentle/moderate & $0.049 * *$ \\
\hline \multirow[t]{2}{*}{$\mathrm{K}\left(\mathrm{cmol}_{\mathrm{c}}(+) / \mathrm{kg}\right)$ soil } & Cultivated land/grazing land & $0.0 * * *$ & Moderate/steep & $0.0^{* * *}$ \\
\hline & Forestland/shrubland & $0.001 * * *$ & Gentle/moderate & $0.0 * * *$ \\
\hline \multirow[t]{2}{*}{$\mathrm{P}\left(\mathrm{mg} / \mathrm{kg}^{2}\right)$} & Grazing land/forestland & $0.0^{* * *}$ & Steep/gentle & $0.007 * *$ \\
\hline & Forestland/shrubland & $0.017 * *$ & Moderate/gentle & $0.014 * *$ \\
\hline \multirow[t]{2}{*}{$\mathrm{OC}(\%)$} & Cultivated land/shrubland & $0.001 * * *$ & Gentle/steep & $0.0 * * *$ \\
\hline & Grazing land/cultivated land & $0.0^{* * *}$ & Steep/moderate & $0.012 * *$ \\
\hline \multirow[t]{2}{*}{$\mathrm{TN}(\%)$} & Shrubland/cultivated land & $0.0 * * *$ & Steep/gentle & $0.0 * * *$ \\
\hline & Grazing land/forestland & $0.0 * * *$ & Gentle/moderate & $0.0 * * *$ \\
\hline \multirow[t]{2}{*}{ PBS } & Shrub land/forest land & $0.014 * *$ & Moderate/gentle & $0.001 * *$ \\
\hline & Grazing land/forestland & $0.007 * *$ & Gentle/steep & $0.0 * * *$ \\
\hline \multirow[t]{2}{*}{ CEC/clay } & Cultivate land/shrubland & $0.0 * * *$ & Steep/gentle & $0.014 * *$ \\
\hline & Forestland/forestland & $0.001 * * *$ & Moderate/gentle & $0.0 * * *$ \\
\hline
\end{tabular}

$* P=0.05, * * P=0.01, * * * P=0.001$ such sites. At the same time, the gentler slope land was more commonly used as pastureland which is also important to maintain the concentration of nitrogen.

As a general fact, the concentration and distribution of nitrogen in the study watershed showed a similar trend with organic carbon concentration among land-use type and slope gradient. For this reason, contents of total nitrogen had positive and significant correlation with SOC ( $r=0.860$, $P<0.05$ ). The low contents of total nitrogen (Landon and Landon 1991) in the study watershed resulted from the low level of soil organic carbon content and mineralization of the existing soil organic matter following cultivation and communal free grazing. The limited use of nitrogen-containing inputs such as commercial fertilizer and plant and animal residues in such continuous cropping land and communal grazing land has contributed to the loss of total nitrogen throughout the study watershed. In the study watershed, crop residues are collected for animal feed, fuel, thatching and temporary construction purposes. Similarly, animal dung and waste are collected for fuel. These could be probably the major factors contributing to low contents of soil organic carbon and consequently the decline of total nitrogen in the soil system.

\section{Available phosphorus}

The result for available $\mathrm{P}$ showed that it varied from 2.08 to $6.34 \mathrm{mg} / \mathrm{kg}$ (Table 4) and was influenced by both slope gradient $(P<0.01)$ and land-use type $(P<0.05)$ (Table 5$)$. It was the highest in forestland and lowest in grazing types of land use. Accordingly, the highest $5.20 \mathrm{mg} / \mathrm{kg}$ and the lowest $(3.26 \mathrm{mg} / \mathrm{kg})$ available phosphor contents were observed 
in forest and grazing land-use type, respectively (Table 4). Although level of available $\mathrm{P}$ can be generally rated as low (Landon and Landon 1991) in the study watershed, there is a decline of $37.5 \%, 23.6 \%$ and $4.6 \%$ in the grazing, shrub and cultivated from forestland, respectively. Contents of available phosphors were higher $(4.98 \mathrm{mg} / \mathrm{kg})$ in gentler slope and the lower $(3.76 \mathrm{mg} / \mathrm{kg})$ in steeper slope gradients. The multiple comparisons also indicated that there is significant difference of available phosphorus content between gentle and steep slope gradients $(P<0.05)$ and between steep and moderate slope gradients $(P<0.01)$ (Table 6). The high concentration of phosphorus in the gentler slopes is related to its removal from steeper and deposition in gentler slope gradients. As is discussed earlier, geomorphic processes of erosion-deposition are responsible in the spatial variations of available $\mathrm{P}$ in the study watershed.

\section{Exchangeable cations}

Exchangeable magnesium $(\mathrm{Mg})$ of a soil was influenced by change in slope gradient $(P<0.01)$ and the interaction effect between land-use change and slope gradient $(P<0.05)$ (Table 5). The average value of exchangeable value of cultivated land, forestland, grazing land and shrubland were $0.86,1.91,1.24$ and $1.31 \mathrm{mg} / \mathrm{kg}^{2}$, respectively (Table 4). The highest exchangeable $\left(1.91 \mathrm{cmol}_{\mathrm{c}}(+) / \mathrm{kg}\right)$ found in the forestland compared to cultivated land $\left(0.86 \mathrm{cmol}_{\mathrm{c}}(+) / \mathrm{kg}\right)$ caused a 54\% decline in the amount of exchangeable magnesium. This result indicated that the conversion of forestland to cultivated land cause a decline in the amount of exchangeable magnesium. Exchangeable magnesium mean values showed differences across slope gradients $(P<0.05)$ (Table 5). The mean value of exchangeable magnesium varied between 1.11 and $1.74 \mathrm{cmol}_{\mathrm{c}}(+) / \mathrm{kg}$ soil across all slope gradients (Table 4). The lower concentration of magnesium was observed in the steeper and moderate slopes than in the gentler slope. The increment of concentration of exchangeable magnesium from the steeper and moderate slope to the gentler slope indicated that there is a downward leaching of basic cations from the steep slope area and accumulated in the gentler slopes.

Exchangeable potassium $(\mathrm{K})$ varied between 0.42 and $1.31 \mathrm{cmol}_{\mathrm{c}}(+) / \mathrm{kg}$ soil and was influenced by land-use type $(P<0.05)$ and slope gradient $(P<0.05$, Table 5$)$. Soil under cultivated land and grazing land had lower exchangeable $\mathrm{K}$ than other LC types (Table 4). Lower K was observed under cultivated soils; the LC change from forestland to cultivated land and grazing land and continuous harvesting without fertilization may lead to decline in exchangeable $\mathrm{K}$ over time. Low level of exchangeable $\mathrm{K}$ in the Gumara watershed may affect plant growth, soil quality and productivity. In the same way, exchangeable sodium $(\mathrm{Na})$ showed difference in land-use type and slope gradient in the study watershed (Table 6).

The value of exchangeable calcium $(\mathrm{Ca})$ presented in Table 4 shows that a range of 11.93 to $20.83 \mathrm{cmol}_{\mathrm{c}}(+) / \mathrm{kg}$ was influenced by slope gradient and land-use type. The mean value of exchangeable calcium (ca) under the forest, the grazing shrub land and the cultivated lands were $17.63,16.24,16.01$ and $14.38 \mathrm{cmol}_{\mathrm{c}}(+) / \mathrm{kg}$, respectively. The exchangeable calcium content of the soil in the study watershed was $(P<0.005)$ influenced by land-use type and $(P<0.05)$ by slope gradient. Considering the three slope gradients, exchangeable calcium was the highest $\left.\left(19.45 \mathrm{cmol}_{\mathrm{c}}(+) / \mathrm{kg}\right)\right)$ in gentler slopes and the lowest $\left(12.76 \mathrm{cmol}_{\mathrm{c}}(+) / \mathrm{kg}\right)$ in the steep slope gradients. The lowest value of exchangeable calcium in the steep slopes could be related to the influence of intensity of cultivation and abundant crop harvest with little or no use of input as indicated by Singh et al. (1995).The multiple comparisons also indicated that there is significant difference of exchangeable calcium between gentle and steep $(P<0.001)$ and between steep and moderate slopes $(P<0.001)$ (Table 6). Exchangeable calcium was positively and significantly correlated with $\mathrm{Mg}\left(r=0.78^{* *}\right)$, CEC $\left(r=0.08^{* *}\right)$, clay $\left(r=0.65^{* *}\right)$ and total $\mathrm{N}\left(r=0.76^{* *}\right)$, while it was inversely and significantly $(P<0.05)$ correlated with sand.

The cation exchangeable capacity (CEC) value of the Gumara watershed was significantly $(P<0.005)$ affected by both slope gradient and $(P<0.005)$ land-use change but not affected by the interaction effect of land-use change and slope gradient $(P>0.05)$ (Table 5). The mean values of CEC ranged from 19.91 to $32.69 \mathrm{cmol}_{\mathrm{c}}(+) / \mathrm{kg}$ in the cultivated and forestland, respectively (Table 4). The high amount of $\mathrm{CEC}$ in the forestland and its decline in the cultivated land may be related to the availability of high soil organic carbon.

CEC values on the gentler slope gradients were significantly different from those on the steeper and moderate slope gradients (Table 4). The values in the gentler slope (29.23 $\left.\mathrm{cmol}_{\mathrm{c}}(+) / \mathrm{kg}\right)$ are higher than values in moderate and steeper slopes $\left(27.26 \mathrm{cmol}_{\mathrm{c}}(+) / \mathrm{kg}\right.$ and $\left.24.28 \mathrm{cmol}_{\mathrm{c}}(+) / \mathrm{kg}\right)$, respectively. The highest CEC value in the gentle slope is related to the availability of high concentration of soil organic carbon and clay content. This is an indication that SOC and clay are major sites for exchangeable cations. CEC depends mainly on the organic matter content and clay content of the soil (Rowell 1994; Wild 1993). Accordingly, it was positively and significantly correlated with clay $\left(r=0.854^{* *}\right)$ and organic carbon $\left(r=0.891^{* *}\right)$, while it was inversely and significantly $(P<0.05)$ correlated with sand $\left(r=-0.768^{* *}\right)$. As a result, it is important to protect removals of clay and organic matter by processes of erosion. The multiple comparisons indicated that there is significant difference of CEC between all types of slope gradients: gentle and steep $(P<0.001)$ and between steep and moderate $(P<0.001)$ 
Table 7 The soil degradation index (SDI) in the cultivated land use of Gumara watershed

\begin{tabular}{llll}
\hline Soil properties & \multicolumn{2}{l}{ Land use type } & Mean difference (SDI) \\
\cline { 2 - 3 } & Cultivated land & Forestland & \\
\hline Organic carbon & 1.64 & 3.44 & -1.8 \\
Nitrogen & 0.06 & 0.14 & -0.08 \\
Phosphorus & 4.39 & 5.20 & -0.81 \\
Potassium & 0.42 & 1.31 & -0.89 \\
Bulk density & 1.37 & 1.31 & 0.06 \\
Total & & & $-3.64(-364 \%)$ \\
\hline
\end{tabular}

Table 8 The soil degradation index (SDI) in the grazing land use of Gumara watershed

\begin{tabular}{llll}
\hline Soil properties & \multicolumn{2}{l}{ Land-use type } & Mean difference (SDI) \\
\cline { 2 - 3 } & Grazing land & Forestland & \\
\hline Organic carbon & 2.59 & 3.44 & -0.85 \\
Nitrogen & 0.11 & 0.14 & -0.03 \\
Phosphorus & 3.30 & 5.20 & -1.90 \\
Potassium & 0.89 & 1.31 & -0.42 \\
Bulk density & 1.45 & 1.31 & 0.14 \\
Total & & & $-3.34(-334 \%)$ \\
\hline
\end{tabular}

(Table 6). This indicated that the continuous and ongoing deposition of sediments on the gentle slope (Moges and Holden 2008) has the impact on the suitability of the soil for cultivation and will put the upper part of the catchment not conducive for agriculture.

\section{Soil degradation index}

Soil degradation index (SDI) was determined as a function of soil organic carbon, bulk density, available phosphorus, exchangeable potassium and total nitrogen of the soil that are crucial for plant growth. The calculated values of the SDI of the selected soil parameters in different land use indicate the level of soil quality in each land-use type.

The soil degradation index of the Gumara watershed ranged from -236 to $-364 \%$. The SDI was highly influenced by land-use type. The highest $(-364 \%)$ was observed under the cultivated land (Table 7). The highest value of SDI in the cultivated land could be an indication of the decline of soil quality due to the removal of the necessary nutrients such as phosphorous, nitrogen, potassium and a deterioration of soil organic carbon and bulk density as a result of over cultivation and poor cropping system as explained above. The study conducted by Fentaw et al. (2006) in the Bale mountain region indicated that the deterioration of soil quality is commonly observed when natural forest was converted to cultivated land.
Table 9 The soil degradation index (SDI) in the shrubland use of Gumara watershed

\begin{tabular}{llll}
\hline Soil properties & \multicolumn{2}{l}{ Land-use type } & Mean difference (SDI) \\
\cline { 2 - 3 } & Grazing land & Forestland & \\
\hline Organic carbon & 2.88 & 3.44 & -0.56 \\
Nitrogen & 0.09 & 0.14 & -0.05 \\
Phosphorus & 3.99 & 5.20 & -1.21 \\
Potassium & 0.88 & 1.31 & -0.43 \\
Bulk density & 1.42 & 1.31 & 0.11 \\
Total & & & $-2.36(-236 \%)$ \\
\hline
\end{tabular}

Table 10 Response of the sampled households whether the rate of erosion is increasing or decreasing in the watershed

\begin{tabular}{lc}
\hline Rate of erosion & Percentage (\%) \\
\hline Increasing & 80.4 \\
Decreasing & 13.4 \\
Not changed & 6.2 \\
Total & $100 \%$ \\
\hline
\end{tabular}

The second highest SDI value (-334\%) of the watershed was observed in the grazing land (Table 8). This as well indicated that the conversion of forestland to grazing land facilitates the decline of soil quality. In line with this, Nael et al. (2004) indicated that deforestation followed by over grazing resulted in the deterioration of the physical, chemical and biological quality of the soil resources.

Relatively low (-292\%) soil quality degradation index of the watershed was observed in the area where forestland was converted to shrubland. This indicated that when the land use is converted from forestland to the shrubland, the decline in the important nutrients of the soil is not as serious as the as the cultivated and the grazing land (Table 9).

\section{Farmers' perception of soil degradation in the study watershed}

As indicate in Table 10, farmers of the study watershed are very well aware of the degradation of soil due to erosion. About $82.6 \%$ of the respondents acknowledged that soil erosion as a problem at least in one of their plots. In addition, about $75.4 \%$ of the respondents acknowledged that erosion is increasing in their plots.

Farmers of the study watershed asserted the presence of soil erosion by expressing the major indicators that resulted following the manifestation of soil erosion in the watershed at varying levels. Hence, $73.4 \%$ and $60.2 \%$ of the respondents expressed that formation of gullies and elimination of formerly grown crops from the watershed to be as the major indicators of the existence land degradation on their lands, 
respectively. Moreover, about $52 \%$ of the farmers of the watershed suggested that decreasing of the depth of the soil as indicators of land degradation. Others (48.5\%) describe the existence of soil erosion by observing the declining of the productivity of the soil. On the other hand, some $22 \%$ of the respondents in the watershed relate the existence of soil erosion with the stoniness of the soil. Thus, the above result and the information obtained from the focus group discussion indicated that soil erosion problem is perceived by the majority of the respondents in terms of reduced productivity of land, gully encroachment and its appearance on arable land, decrease in the capacity of soil to grow a variety of crops, decrease in the depth of top soil, decline in the water holding capacity of soils and decline in yield from the farm (Tables 11, 12, 13).

Regarding the causes of soil erosion, most respondents mentioned topography of the land (71\%). Participants in the focus group discussion mentioned that one of the major causes of soil degradation is the steepness of the land itself. They added that during torrential and sudden rainfall, it is not uncommon to see down slope movement of huge amount of soil. The absence of fallowing was mentioned as the other factor of land degradation in the study area (64\%). Shortage of arable land together with increasing interest of farmers to produce more food crops made fallowing to be a forgotten activity in the study watershed. As a result of this, farmers are forced to crop their land continuously which in turn makes the soil susceptible for erosion. In line with this, Shiferaw and Holden (1998) stated that due to increasing intensification and continuous cultivation on sloping lands without supplementary use of soil amendment and conservation practice, the vast

Table 11 Farmers' perception on the presence of soil degradation

\begin{tabular}{ll}
\hline Indicators of erosion & Responses $(\%)$ \\
\hline Formation of gullies & 73.4 \\
Decreasing in the depth of the soil & 52 \\
The stoniness of the soil & 22 \\
Decreasing of the productivity of the soil & 48.5 \\
Elimination of the formerly grown crops & 60.2 \\
\hline
\end{tabular}

Table 13 Reasons for soil productivity decline

\begin{tabular}{lcc}
\hline Reasons for soil productivity decline & No & $\%$ \\
\hline Loss of nutrients & 53 & 44.2 \\
Little or no use of fallowing & 41 & 34.2 \\
Aging of the land & 26 & 21.6 \\
Total & 120 & 100 \\
\hline
\end{tabular}

area of Ethiopian highlands could be classified as severe to moderate soil degradation level.

About $56 \%$ of the respondents indicated that deforestation as the cause for the removal of soil (Fig. 3). The cutting of trees for various activities such as, for the making of farming utensils, construction purpose, and expansion of cropping land and as a source of fuel wood is common in the Gumara watershed. As a result, many areas in the watershed are seen as devoid of any forms of vegetation cover.

Productivity decline of land is related to different factors. About $85 \%$ of the respondents in the Gumara watershed associated this with the loss of soil nutrients. Due to removal of vegetation and continuous cropping, the soil becomes easily susceptible to erosion. Little or no fallowing is also another factor indicated by the households as a responsible factor for the decline of productivity in the watershed. About $65 \%$ of the respondents agreed the absence of fallowing as the cause for the decline of land productivity in the study watershed. The participants in the focus group discussion also expressed that fallowing is limited due to scarcity of land for agriculture. The other factor related to the decline in land productivity is aging of the land. About $43 \%$ of the respondents agreed the decline of productivity in the watershed is related to the cultivation of the land for a long period of time without rest. Studies so far made convincingly indicated that short fallow period, aging of the land and nutrient depletion are widely observed in different parts of Ethiopia (Gete and Hurni 2001; Woldeamlak 2003).
Table 12 Perception of farmers on soil productivity decline of the Gumara watershed

\begin{tabular}{|c|c|c|c|c|c|c|c|c|}
\hline \multirow{3}{*}{$\begin{array}{l}\text { Is soil productivity } \\
\text { declining }\end{array}$} & \multicolumn{6}{|c|}{ Slope gradients of the watershed } & \multirow{2}{*}{\multicolumn{2}{|c|}{ Total }} \\
\hline & \multicolumn{2}{|c|}{ Steep slope } & \multicolumn{2}{|c|}{ Moderate slope } & \multicolumn{2}{|c|}{ Gentle slope } & & \\
\hline & No & $\%$ & No & $\%$ & No & $\%$ & No & $\%$ \\
\hline Yes & 30 & 75 & 25 & 62.5 & 12 & 30 & 67 & 55.8 \\
\hline No & 10 & 25 & 15 & 37.5 & 28 & 70 & 53 & 44.2 \\
\hline Total & 40 & 100 & 40 & 100 & 40 & 100 & 120 & 100 \\
\hline
\end{tabular}


Fig. 3 Perceived causes of soil degradation in the Gumara watershed

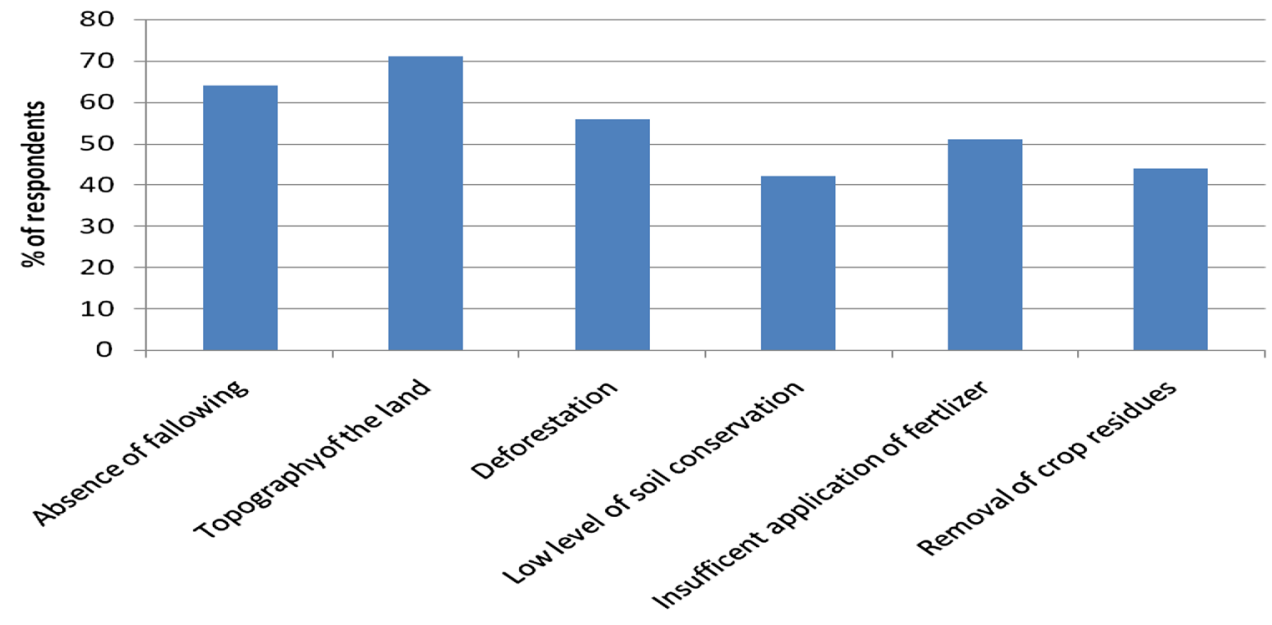

Percived cause of soil erosion

\section{Conclusion}

The combined effects of land cover change and variation in slope gradient caused significant change in the quality of the soil in the Gumara watershed. The influence on most soil parameters was negative following the land-use change from the forestland to shrubland, grazing land and cultivated land. The change in slope gradient and land use not only causes change in the content of the soil particles but also the change in the spatial distribution. For instance, OC, N, CEC, $\mathrm{K}$, clay and $\mathrm{PH}$ soil parameters in the watershed are the highest in the lower slope and relatively low in the moderate and steeper slope gradients where soil erosion is maximum.

The calculated deterioration indices of the soil quality parameters (bulk density, soil organic carbon, total nitrogen, phosphorus and potassium) at the surface layer $(0-20 \mathrm{~cm})$ showed negative values in the cultivated land, grazing land and shrubland as compared to the values of the forestland which was relatively undisturbed. The highest deterioration index value $(-364 \%)$ was observed under cultivated land and the least $(-236 \%)$ was recorded in the shrubland. The degradation value in the watershed clearly indicated that the conversion of forestland to other land-use types by human interaction is the major factor for the cause of soil quality decline in the watershed.

The decline of soil quality in the Gumara watershed is not only related to land-use conversion, there are also some other direct and indirect causes related to it. The direct cause of soil quality degradation including decline in the use of fallowing, removal of crop residues from the top soil, limited application of chemical fertilizer, deforestation and over grazing is apparent and generally agreed by the farmers of the study area. In addition to this, the process of prolonged use of lands for crop production with no or only little inputs has exacerbated soil quality decline leading to soil degradation, which may ultimately lead to complete loss of the productivity of land and prevents sustainable use of land resources. Therefore, the control of such damaging effects would require proper land management strategies such as agro forestry, crop rotation, fallowing, terracing and proper land-use planning. Further research on soil quality and integrated land resource to introduce land-use planning for sustainable land resource management practice in the Gumara watershed is required.

Open Access This article is distributed under the terms of the Creative Commons Attribution 4.0 International License (http://creativeco mmons.org/licenses/by/4.0/), which permits unrestricted use, distribution, and reproduction in any medium, provided you give appropriate credit to the original author(s) and the source, provide a link to the Creative Commons license, and indicate if changes were made.

\section{References}

Achalu C, Heluf G, Kibebew K, Abi T (2012) Status of selected physicochemical properties of soils under different land use systems of Western Oromia, Ethiopia. J Biodivers Environ Sci 2(3):57-71

Alemayehu K (2007) Effects of different land use systems and topography on selected soil properties at Delbo watershed, Wolayta zone, southern Ethiopia. Msc thesis, Hawasa University, Hawasa, Ethiopia

Black CA, Evans DD, Dinauer RC (1965) Methods of soil analysis (vol 9, pp 653-708). Madison, WI: American Society of Agronomy

Bouyoucos GJ (1962) Hydrometer method improved for making particle size analyses of soils. Agron J 54(5):464-465

Bovine P, Schaffer B, Stuny W (2000) Quantifying the relationship between soil organic carbon and soil physical properties using shrinkage modeling. Eur J Soil Sci 60(4):265-275

Brubaker SC, Jones AJ, Lewis DT, Frank K (1993) Soil properties associated with landscape position. Soil Sci Soc Am J 57(1):235-239

Buscot F (2005) What are soils? Microorganisms in soils: roles in genesis and functions. Springer, Berlin, Heidelberg, pp 3-17

Chapman HD (1995) Cation exchange capacity. In: Black CA, Ensiminger LE, Clark FE (eds) Methods of soil analysis. Agronomy. American Society of Agronomy Inc, Madison, pp 9891-9901 
Compos CA, Oleschko LK, Elchevers BJ, Hidalgo MC (2007) Exploring the effect of change in land use on soil quality on the eastern slope of the Cofre de Perote Volcano (Mexico). Forest Ecol Manag 248:174-182

CSA (Central Statistical Authority) (2007) Summary and statistical report of population and Housing census of Ethiopia. Central Statistical Agency, Addis Ababa

Doran JW, Parkin TB, Jones AJ (1996) Quantitative indicators of soil quality: a minimum data set. Methods Assess Soil Qual 1996:25-37

Duff B, Rasmusen-Smiley RW (1995) Wheat fallow systems in semiarid regions of the pacific, north-west America. In: Barnett V, Paynet R, Steiner R (eds) Agricultural suitability, pp 85-109

EMS (Ethiopian Meteorological Service) (2013) Ethiopian meteorological service data base (1973-2005). Ethiopian Meteorological Service, Addis Ababa

Ethiopian Meteorological Service (EMS) (2014) Ethiopian meteorological service data base (1973-2005). Ethiopian Meteorological Service, Addis Ababa

Fentaw Y, Ledin S, Abdu A (2006) Soil property variation in relation to topographic aspects and vegetation community in the south eastern high lands of Ethiopia. For Ecol Manag 232(1):90-99

Garcia A, Rodrigueze B, Garcia B, Gabaric N, Krajovic V, Zimakova M (1990) Mineral nutrients in pasture herbage of central western Spain. Soil, grassland and animal relationship. In: Proceedings of 13th general meeting of the European grassland. Banska Bystorica, Czechoslovakia

Gete Z, Hurni H (2001) Implication and land use/land cover dynamics for mountain resource degradation in the Northwestern Ethiopia Highlands. Mountain Res Dev 21:184-191

Grace PR, Oades JM, Keith H, Hancack TW (1995) Trends in wheat yields and soil organic carbon in permanent rotation trial at the Waite Agricultural research Institute, South Australia. Aust J Exp Agric 35:857-864

Gregorich EG, Greer KJ, Anderson DW, Liang BC (1998) Carbon distribution and losses: erosion and deposition effects. Soil Tillage Res 47(3):291-302

Griffiths BS, Ball BC, Daniell TJ, Hallett PD, Neilson R, Wheatley RE, Bohanec M (2010) Integrating soil quality changes to arable agricultural systems following organic matter addition, or adoption of a ley-arable rotation. Appl Soil Ecol 46(1):43-53

Hendershot WH, Courchense F, Schemenauer RS (1992) Soil acidification along a trophic gradient on round top mountain, Quebec, Canada. Water Air Soil Pollut 61(4):235-242

Husien H, Mohamed A, Melanie D (2015) Impacts of land use and land cover changes and topographic aspects on soil quality in the Kasso catchment, Bale Mountains of the south eastern Ethiopia. Singap J Trop Geogr 36:357-375

Islam KR, Weil RR (2000) Land use effects on soil quality in a tropical forest ecosystem of Bangladesh. Agr Ecosyst Environ 79(1):9-16

Jing WJ, Yue X, Hui-Chun Y, Chong YS, Yuan FH (2011) Effects of land use and soil management particles on soil fertility quality in north china cities urban fringe. Afr J Agric Res 6(11):2059-2065

Landon JR, Landon JR (1991) Booker tropical soil manual: a handbook for soil survey and agricultural land evaluation in the tropics and subtropics (no. 631.4713 B6)

Li Y, Lindstrom MJ (2001) Evaluating soil quality—soil redistribution relationship on terraces and steep hillslope. Soil Sci Soc Am J 65(5):1500-1508

Lambin G, Esu IE (2011) Characteristics and management problem of vertisols in the Nigerian Savanah

Landon JR (1994) Booker tropical soil manuala handbook for soil survey and agricultural land evaluation in the tropics and subtropics. No. 631.4713 B6
Lukman NM (2004) Land use effects on soil quality and productivity in the Lake Victoria basin of Uganda (PhD thesis). Department of soil science, Ohio state university, Columbus, Ohio

McDonagh JF, Thomsen TB, Magid J (2001) Soil organic matter decline and compositional change associated with cereal cropping in southern Tanzania. Land Degrad Dev 12(1):13-26

Moges A, Holden NM (2008) Soil fertility in relation to slope position and agricultural land use: a case study of Umbulo Catchment in Southern Ethiopia. Environ Manag 42(5):753-763

Mulugeta L (2004) Effects of land use changes on soil quality and Native Floral Degradation and Restoration in the highlands of Ethiopia (PhD thesis). Departments of forest soils, Swedish University of Agricultural Sciences, Upsla, Sweden

Nael M, Khademi H, Hajabbasi MA (2004) Response of soil quality indicators and their spatial variability to land degradation in central Iran. Appl Soil Ecol 27(3):221-232

Nega E, Heluf G (2009) Influence of land use changes and soil depth on cation exchange capacity and contents of exchangeable bases in the soils of Senbate Watershed, West Ethiopia. Ethiop J Natural Res 11(2):195-206

Negassa W, Heluf G (2004) The impact of different land use systems on soil quality of Alfisols of western Ethiopia. Rural poverty reduction through research for development and transformation. Deutscher Tropentag, Berlin. www.tropentag.de/2004/abstracts/ full, p 265

Olsen SR (1954) Estimation of available phosphorus in soils by extraction with sodium bicarbonate

Pondo MM, Jurado E, Mozano M, Estrado E (2004) The effect of land use on desertification process. J Range Manag 57:320-324

Rowell DL (1994) Soil sciences: methods and applications. Addison Wesley Longman Singapore publishers (pte) Ltd, England

Shiferaw B, Holden ST (1998) Resource degradation and adoption of land conservation technologies in the Ethiopian highlands: a case study in Andit Tid, North Shewa. Agric Econ 18(3):233-247

Singh CJ, Goh KM, Bond WJ, Freney JR (1995) Effects of organic and inorganic calcium compounds on soil solution $\mathrm{pH}$ and $\mathrm{Al}$ concentration. Eur J Soil Sci 45:53-63

South Gondar Zone Office of Agriculture (SGZOA) (2013) Population data base document of South Gondor Zone, 1984-2013 (in Amharic) (Unpublished report, pp 81). Debre Tabor

Van Reeuwijk LP (1992) Procedure for soil analysis. ISRlC, Wageningen, The Netherland, $\mathrm{p} 56$

Wakene N (2001) Assessment of important physicochemical properties of Alfisols under different management systems in Bako area, Western Ethiopia (Doctoral dissertation, M. Sc. Thesis, School of Graduate Studies, Alemeya University, Ethiopia)

Walkley A, Black IA (1934) An examination of the Degtjareff method for determining soil organic matter, and a proposed modification of the chromic acid titration method. Soil Sci 37(1):29-38

Wild A (1993) Soils and the Environment. Cambridge University Press, Cambridge

Wolde M, Veldkamp E, Mitiku H, Nyssen J, Muys B, Kindeya G (2007) Effectiveness of enclosures to degraded soils as a result of overgrazing in Tigray, Ethiopia. J Arid Env 69:270-284

Woldeamlak B (2003) Towards integrated watershed management in highland Ethiopia: the Chemoga watershed case study (vol 44). Wageningen University and Research Centre

Woldeamlak B, Stroosnijder L (2003) Effects of agroecological land use succession on soil properties in Chemoga watershed, Blue Nile basin, Ethiopia. Geoderma 111(1):85-98

Publisher's Note Springer Nature remains neutral with regard to jurisdictional claims in published maps and institutional affiliations. 